\title{
Application of Alkaline Phosphatases from Different Sources in Pharmaceutical and Clinical Analysis for the Determination of Their Cofactors; Zinc and Magnesium Ions
}

\author{
Svetlana V. Muginova, Anna M. Zhavoronkova, Alexei E. Polyakov, and \\ Tatyana N. SHEKHOVTSOVA ${ }^{\dagger}$
}

Chemistry Department, M. V. Lomonosov Moscow State University, Leninskie Gory, Moscow 119992 GSP-2, Russia

\begin{abstract}
Prospects of using different alkaline phosphatases bearing zinc and magnesium ions in their catalytic and allosteric sites, respectively, in pharmaceutical and clinical analysis were demonstrated. Also their application for the determination of zinc in insulin to control injection quality and magnesium in human urine for the diagnosis and treatment of magnesium deficiency was shown. The reaction of $p$-nitrophenyl phosphate hydrolysis was chosen as an indicator. The choice of appropriate alkaline phosphatase was substantiated, the influence of the nature of buffer solutions on the behavior of the enzyme-metal systems was studied, and the conditions of the indicator reaction proceeding in the presence of sample matrixes were optimized. Simple, rapid, sensitive, and selective enzymatic procedures for determining zinc and magnesium based on their inhibiting and activating effects on the catalytic activity of alkaline phosphatases from seal and chicken intestine, respectively, were developed.
\end{abstract}

(Received September 6, 2006; Accepted November 24, 2006; Published March 10, 2007)

\begin{abstract}
Alkaline phosphatases (EC 3.1.3.1) belong to the class of hydrolases and catalyze alkaline hydrolysis of a great number of different phosphoric acid esters. ${ }^{1}$ Alkaline phosphatases are widely spread in nature. ${ }^{1,2}$ Nowadays, alkaline phosphatases are isolated from various sources (microorganisms, tissues of different organs, body and connected tissues of invertebrates and vertebrates; animals and human beings). Alkaline phosphatases are often divided into 4 groups (isozymes) depending on their source of isolation. ${ }^{1-3}$ Three of them are found exclusively in intestine, placenta and germ cells. The fourth isozyme has been termed tissue non-specific alkaline phosphatase, because of its wide tissue distribution. Alkaline phosphatases from hepatic, skeletal, renal tissues represent this group of indicated enzymes. An alternative opinion on the classification of alkaline phosphatases isozymes was proposed by Iino. ${ }^{4}$ Many preparations of the above-mentioned alkaline phosphatases are commercial.
\end{abstract}

A family of alkaline phosphatases is applied in chemical analysis for solving a wide spectrum of analytical problems. It is very important to identify and/or determine each isozyme in clinical practice because any change in the catalytic activity of alkaline phosphatase isozymes (for instance, in blood, tissues) is accomplished by various pathological states (hepatitis, different diseases of bones, heavy hereditary diseases, prostate cancer and etc.). ${ }^{4,5}$ Alkaline phosphatases (especially from Escherichia coli) are widely used as enzymatic labels in immunoassay for determining herbicides, pesticides, and different biologically active organic compounds. ${ }^{6,7}$

The highly sensitive and selective procedures for the determination of zinc, lead, magnesium, and calcium are based on their inhibiting, activating or reactivating effects on the

$\uparrow$ To whom correspondence should be addressed.

E-mail: tnshekhov@analyt.chem.msu.ru catalytic activity of native and immobilized intestinal alkaline phosphatases or their apoforms. ${ }^{8}$ It is known that intestinal alkaline phosphatases are distinguished by the highest catalytic activity. $^{2}$ That is why this isozyme has attracted special attention of those biochemists who are developing procedures for the determination of metal ions.

The developed enzymatic procedures were successfully applied for the analysis of environmental (water of different origin, soils), and biological (blood serum, urine) samples as well as food products (peas, grapes, beef, pork). These procedures and aspects of their application in the analysis of real samples were discussed in details earlier. ${ }^{8-10}$

In the present work, we focused on the application of intestinal alkaline phosphatases of animal origin in pharmaceutical and clinical analysis for the determination of zinc and magnesium ions, respectively. Alkaline phosphatase is a metalloenzyme. The essential role of zinc and magnesium in catalyzing and stabilizing the structure of this enzyme was recognized long ago. ${ }^{11}$ Cloetens ${ }^{12,13}$ has shown that $\mathrm{Zn}$ is a prosthetic group of alkaline phosphatase, and it appears to be an integral part of the insulin molecule. Zinc is necessary both for the preservation of the enzyme structure and for the catalytic activity of alkaline phosphatase. Magnesium controls the occupancy of the catalytic and structural binding sites, and modulates the resultant enzymatic activity. ${ }^{11,14}$ Peculiarities in the structure and function of alkaline phosphatases, the simultaneous presence of zinc and magnesium in the enzyme molecular especially, aroused our profound long-term interest in this class of enzymes.

While studying a number of oxidases (peroxidases, alcohol dehydrogenases) and hydrolases (acid and alkaline phosphatases) isolated from diverse sources, we showed that even negligible differences in the structure of isozymes may be purposely used for the development of highly sensitive and selective procedures for the determination of biologically active inorganic and 
organic compounds: metal ions, ${ }^{9,15}$ metalloorganic compounds, ${ }^{16}$ phenols, ${ }^{17}$ and ascorbic ${ }^{18}$ and fatty acids. ${ }^{19}$ In this work, the results of studying the properties of different alkaline phosphatases were applied for the development of highly sensitive and selective procedures for the determination of zinc in an insulin zinc suspension to control its quality and magnesium in urine for the diagnostics and treatment of $\mathrm{Mg}$ deficiency.

The majority of insulin preparations registered in the Russian pharmaceutical market have a prolonged effect. Insulin zinc suspensions (IZS) represent this type of insulin preparation. Their prolonged therapeutic effect is caused by the presence of zinc traces in injections prepared based on an acetic buffer solution with a neutral $\mathrm{pH}$ value. Zinc and some transition metals are present in the majority of buffers and other reagents, and may affect the processing and/or storage of biological pharmaceuticals, such as insulin. Thus, it is necessary to control the zinc content in IZS to guarantee their high quality and therapeutic usefulness. ${ }^{20,21}$

Recently estimating Mg-deficiency has become of considerable interest. This disease may be caused by different reasons (imbalanced diet, stress, physical efforts or hypodinamiya, alcoholism, hormonal contraception, reception of diuretics, etc.).22 The magnesium status is commonly determined while analyzing venous blood or hair with the help of atomic-absorption and atomic emission spectrometry (inductively coupled plasma mass spectrometry).22,23

To develop highly sensitive, selective, simple, and cheap procedures for the determination of zinc and magnesium, we studied three alkaline phosphatases isolated from E. coli (ALPI), chicken intestine (ALPII) and slim intestine of Greenland seal (ALPIII). The hydrolysis of $p$-nitrophenyl phosphate (NPP), giving rise to a colored product, a $p$ nitrophenolate ion, at $\mathrm{pH} 9.8$ was used as an indicator reaction for monitoring the catalytic activity of enzymes. According to literature data, ${ }^{8}$ this reaction provides high catalytic activity of all the considered alkaline phosphatases.

\section{Experimental}

\section{Reagents and chemicals}

All of the reagents were of the best quality available, and deionized water with a resistance of $18.2 \mathrm{M} \Omega \mathrm{cm}^{-1}\left(25^{\circ} \mathrm{C}\right)$ purified with a Simplicity Proto system (Millipore) was used throughout the experiment.

Enzymes. Preparations of alkaline phosphatase from Escherichia coli (33.8 U/mg, Sigma) and slim intestine of a Greenland seal Phoca Groenlandica (13 U/mg, Biolar, Latvia) were used as their homogeneous suspensions in a $2.5 \mathrm{M}\left(\mathrm{NH}_{4}\right)_{2} \mathrm{SO}_{4}$ solution; alkaline phosphatase from chicken intestine was a lyophilized powder from Sigma $(0.4 \mathrm{U} / \mathrm{mg})$. Less concentrated solutions of the ALPI and ALPIII were prepared immediately before work by successive dilution of stock solutions with a $0.05 \mathrm{M}$ Tris- $\mathrm{HCl}$ buffer solution ( $\mathrm{pH}$ 9.8). The solutions of the ALPII were prepared daily by dissolving an accurately weighed amount of the preparation in the same buffer solution. Solid preparations and solutions of the enzymes were stored in a refrigerator at $+4^{\circ} \mathrm{C}$.

Substrate. We prepared $3.3 \mathrm{mM}$ solution of p-nitrophenyl phosphate daily by dissolving disodium $p$-nitrophenyl phosphate hexahydrate (Sigma) in water.

Tris(hydroxymethyl)aminomethane (Tris) (Serva, Germany), glycine, $\mathrm{Na}_{2} \mathrm{~B}_{4} \mathrm{O}_{7} \cdot 10 \mathrm{H}_{2} \mathrm{O}, \mathrm{Na}_{2} \mathrm{CO}_{3}$, and $\mathrm{KOH}$ (Reakhim, Russia) were used to prepare buffer solutions.
Stock standard solutions (1.5 $\mathrm{mg} \mathrm{ml}^{-1}$ ) of Fe(III), $\mathrm{Zn}(\mathrm{II})$, and $\mathrm{Pb}$ (II) were prepared by dissolving samples of spectrochemically pure metals in $\mathrm{HCl}$ and $\mathrm{HNO}_{3}$, respectively. Stock standard solutions (1.5 $\left.\mathrm{mg} \mathrm{ml}^{-1}\right)$ of $\mathrm{Co}(\mathrm{II}), \mathrm{Cu}(\mathrm{II}), \mathrm{Ni}(\mathrm{II})$, $\mathrm{Cd}(\mathrm{II}), \mathrm{Al}(\mathrm{III})$ were prepared by dissolving samples of their chlorides in water acidified to $\mathrm{pH} 2.5$ with $\mathrm{HCl}$. A stock standard solution $\left(25 \mathrm{mg} \mathrm{ml}^{-1}\right.$ ) of $\mathrm{Ca}$ (II) was prepared by dissolving $\mathrm{CaCl}_{2} \cdot 2 \mathrm{H}_{2} \mathrm{O}$ in water. The exact concentrations of these solutions were determined volumetrically. Solutions of lower concentrations of all metal ions were prepared daily by a successive dilution of the stock solutions with acidified water. A working solution of $\mathrm{Mg}$ (II) was prepared from the standard solution of $\mathrm{MgCl}_{2}$ with a concentration of $200 \mathrm{mg} \mathrm{ml}^{-1}$ (Sigma). Solutions of $\mathrm{KCl}$ and $\mathrm{CsCl}$ (160 and $400 \mathrm{mg} \mathrm{ml}^{-1}$, respectively) were prepared from their salts.

Solutions of $\mathrm{HCl}$ for the decomposition of IZS injection and human urine were prepared from a $37 \%$ concentrated hydrochloric acid solution.

\section{Apparatus}

A Shimadzu spectrophotometer (Model UV-220, Japan) with a quartz cell was used for absorbance measurements $(\lambda=400$ $\mathrm{nm} ; l=1 \mathrm{~cm}$; reference solution, water). A pH-meter (EconicsExpert-001, Russia) was used for $\mathrm{pH}$ measurements of aqueous solutions with an accuracy of \pm 0.005 . A flame atomicabsorption spectrometer (Model Perkin Elmer AAS 603) was employed (wavelength: $\mathrm{Zn}, 213 ; \mathrm{Mg}, 258.2$ ). Graduated ground-glass stopper tubes were cleaned with concentrated high-purity grade $\mathrm{HNO}_{3}$, thoroughly washed with deionized water, and sterilized in an air-sterilizer "GP-20" (Russia).

\section{Procedure}

General procedure. The following components were placed sequentially into a glass test-tube with a ground-glass stopper: a certain buffer solution (with the definite $\mathrm{pH}$ value), solutions of the enzyme and metal ion. Finally, an NPP solution was introduced. The total volume of the reaction mixture was 6.00 $\mathrm{ml}$. At the moment when NPP was added and the component solutions were mixed, a stop-watch was started and the absorbance was measured at $15 \mathrm{~s}$ intervals for $2 \mathrm{~min}$. According to the obtained data, kinetic curves were plotted as absorbance $(A)$ versus time $(t, \mathrm{~s})$, and the slopes of the kinetic curves $(\tan \alpha)$ were calculated. Blank experiments were carried out in the absence of a metal ion.

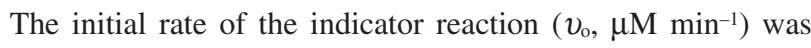
calculated as $v_{\mathrm{o}}=\Delta c / \Delta t=\Delta A / \Delta t \cdot l / l \varepsilon=\tan \alpha / l \varepsilon$, where $\Delta c$ is an increment of the $p$-nitrophenolate concentration at the reaction time $(\Delta t), A$ is the light absorption, $l$ is the cell length, $\varepsilon$ is the molar absorbance coefficient of $p$-nitrophenolate $\left(1.7 \times 10^{4} \mathrm{M}^{-1}\right.$ $\mathrm{cm}^{-1}$ ) and $\tan \alpha$ is the slope of the absorbance $(A)$ graph versus time $(t, \mathrm{~s})$.

The rate of the indicator reaction under its optimum conditions in the absence of phosphatases was less than $1 \%$ of the rate of the enzymatic reaction; that is why all experiments were performed at room temperature without thermostatting.

The degree of enzyme inhibition $(I, \%)$ in the presence of $\mathrm{Zn}$ (II) (or $\mathrm{Zn}$ (II) and other metal ions) and the degree of activation $(A, \%)$ in the presence of $\mathrm{Mg}$ (II) (or $\mathrm{Mg}(\mathrm{II})$ and other metal ions) were calculated from the following equations:

$$
I, \%=100 \cdot\left(v_{\mathrm{o}}-v_{\mathrm{I}}\right) / v_{\mathrm{o}} ; A, \%=100 \cdot\left(v-v_{\mathrm{o}}\right) / v_{\mathrm{o}}
$$

where $v_{0}, v_{\mathrm{I}}$ and $v$ are the values of the rate of the enzymatic reaction in both the absence and presence of metal ions, $\mathrm{Zn}$ (II) and $\mathrm{Mg}(\mathrm{II})$, respectively. 
Treatment of the insulin sample. The insulin preparation "Monotard", purchased from "Novo Nordisk" (Denmark), was a mixture of amorphous and crystalline insulins in a ratio of 3:7 and contained methylparaben to protect against microbial contamination and $\mathrm{NaCl}$ as an isotonic agent. An insulin sample was treated by $6 \mathrm{M} \mathrm{HCl}(40 \mu \mathrm{l}$ of acid per $10 \mathrm{ml}$ of IZS injection) and was diluted with water 10 -fold before introducing into the reaction mixture.

Procedure of zinc determination in INS. First, $4.7 \mathrm{ml}$ of a $5 \mathrm{mM}$ borate buffer solution ( $\mathrm{pH}$ 9.8), $0.1 \mathrm{ml}$ of $0.6 \mu \mathrm{M}$ ALPIII, 0.1 $\mathrm{ml}$ of the insulin sample (decomposed and diluted as described above), and $0.1 \mathrm{ml}$ of the standard solution of $\mathrm{Zn}$ (II) with the concentrations $2.5,5.0,7.5,10.0 \mu \mathrm{g} \mathrm{ml}^{-1}(0.05,0.1,0.15,0.20$ $\mu \mathrm{g} \mathrm{ml}^{-1}$ in the reaction mixture) were placed sequentially into a glass test-tube with a ground-glass stopper. It was very important to keep the definite sequence of introducing the standard additions of zinc and the analyzed sample. Finally, 1.0 $\mathrm{ml}$ of $3.3 \mathrm{mM}$ NPP was introduced. The total volume of the reaction mixture was $6.0 \mathrm{ml}$. At the moment when NPP was added and the reaction solution was mixed, a stop-watch was started and the absorbance was measured at $15 \mathrm{~s}$ intervals for 2 min. A blank experiment was carried out according to the same procedure, omitting insulin and zinc standard solutions (the volume of the introduced buffer solution was $4.8 \mathrm{ml})$.

Kinetic curves of the absorbance $(A)$ versus time $(t, \mathrm{~s})$ were plotted according to the obtained data, and the rate of the indicator reaction was calculated as described above. The zinc concentration in the sample was calculated based on the calibration curve plotted in the coordinates: the rate of the reaction, $\mu \mathrm{M} \mathrm{min}{ }^{-1}$; zinc concentration, $\mu \mathrm{g} \mathrm{ml}^{-1}$. It should be noted that the calibration graph was linear in the zinc concentration range of $0.1-1 \mu \mathrm{g} \mathrm{ml}^{-1}$, unlike the calibration curve in a wide $\left(0.01-1 \mu \mathrm{g} \mathrm{ml}^{-1}\right)$ range of zinc concentrations, given with a logarithmic expression.

Urine samples selection and pretreatment. Urine samples excreted during $24 \mathrm{~h}$ were collected in pure glass bottles. The bottles were cleaned with diluted nitric acid and deionized water in sequence. Aliquots $(15.00 \mathrm{ml})$ of the samples were placed in flasks and heated cautiously until vapor appearance. Then, 0.1 $\mathrm{ml}$ of $1 \mathrm{M} \mathrm{HCl}$ was added to every aliquot $(6.00 \mathrm{ml})$ of heated urine. The decomposed samples were transferred into the standard flasks and diluted up to definite volumes by water with $\mathrm{pH} 5.5$ 6.0. Measuring the rate of the reaction in the presence of an undiluted sample and comparing it with the rate of the reaction in the presence of the standard magnesium solution with different concentrations conditioned the multiplicity of urine dilution.

Procedure of magnesium determination in urine. First, $4.7 \mathrm{ml}$ of a $0.5 \mathrm{M}$ Tris- $\mathrm{HCl}$ buffer solution ( $\mathrm{pH} 9.8), 0.1 \mathrm{ml}$ of $36 \mu \mathrm{M}$ ALPII, $0.1 \mathrm{ml}$ of the analyzed sample (diluted urine), and $0.1 \mathrm{ml}$ of the standard solution of magnesium with the concentrations $0.06,0.3,0.6 \mu \mathrm{g} \mathrm{ml}^{-1}\left(1.0,5.0,10.0 \mathrm{ng} \mathrm{ml}^{-1}\right.$ in the reaction mixture) were placed sequentially into a glass test-tube with a ground-glass stopper. Finally, $1 \mathrm{ml}$ of $3.3 \mathrm{mM}$ NPP was introduced. The total volume of the reaction mixture was 6.0 $\mathrm{ml}$. The concentration of Tris- $\mathrm{HCl}$ buffer solution was enhanced to $0.5 \mathrm{M}$ to stabilize the optimum $\mathrm{pH}$ value and to eliminate the interference of urine matrixes with different acidity. The following steps of the procedure were the same as they were in the case of insulin analysis.

\section{Results and Discussion}

Choice of alkaline phosphatases

To choose appropriate alkaline phosphatases prospective for

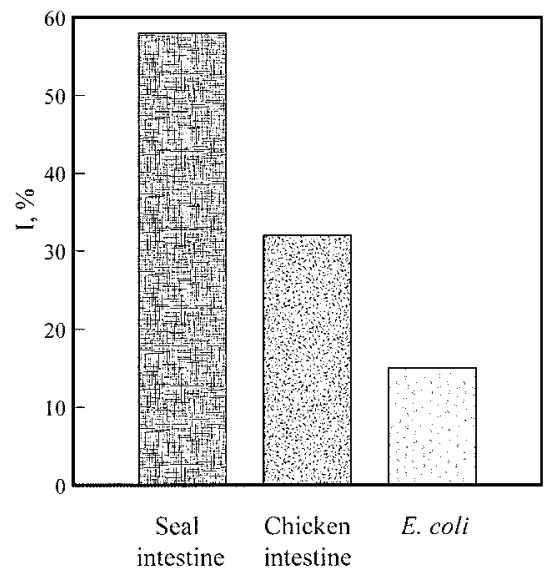

Fig. 1 Relationship between the degree of inhibition of alkaline phosphatases isolated from diverse sources and the zinc concentration in a $50 \mathrm{mM}$ Tris- $\mathrm{HCl}$ buffer solution, $\mathrm{pH} 9.8$.

the development of sensitive procedures for zinc and magnesium determination, the effect of these metal ions on the catalytic activity of all indicated enzymes was studied. All experiments were carried out under the optimum conditions found earlier: ${ }^{9} 50 \mathrm{mM}$ Tris-HCl buffer solution, $\mathrm{pH}$ 9.8; enzyme concentrations, 12 (I), 600 (II), $10 \mathrm{nM}$ (III); NPP, $0.55 \mathrm{mM}$ (I III). The general technique is described in Procedure.

We found that $\mathrm{Zn}$ (II) over a wide range of its concentrations (0.05-50 $\left.\mu \mathrm{g} \mathrm{ml}^{-1}\right)$ inhibited the catalytic activity of three enzymes, but to a different extent (Fig. 1). The same degree of inhibition, $25 \%$ in particular, was observed for alkaline phosphatases I, II, and III at zinc concentrations of 5.0, 0.5, and $0.25 \mu \mathrm{g} \mathrm{ml}^{-1}$, respectively. Thus, ALPIII seemed to be the most sensitive enzyme to the inhibiting effect of zinc in the reaction of NPP hydrolysis.

It was stated that $\mathrm{Mg}(\mathrm{II})$ in its concentration range of $2-20 \mathrm{ng}$ $\mathrm{ml}^{-1}$ activated ALPII $\left(A=600 \%\right.$ at $\left.c_{\mathrm{Mg}(\mathrm{II})}=20 \mathrm{ng} \mathrm{ml}^{-1}\right)$ effectively; the degree of ALPI activation was much lower $(A=$ $20 \%$ at $c_{\mathrm{Mg}(\mathrm{II})}=0.2 \mu \mathrm{g} \mathrm{ml}^{-1}$ ), and the catalytic activity of ALPIII did not change at all in the presence of magnesium. The different influence of the magnesium concentration on the catalytic activity of alkaline phosphatases isolated from calf intestine and the hepatopancreas of shrimp was reported earlier. ${ }^{24}$ The mechanism of the magnesium effect on different alkaline phosphatases has still not been clarified. In our opinion, the activation of the two above-mentioned alkaline phosphatases with magnesium might be explained, for instance, by the presence of the so-called "liophylic" part in the enzyme molecule, the connection of which with magnesium ions provides better binding of the substrate; the activation degree depends on the content of such a liophylic part in the enzyme molecule. ${ }^{25}$

Thus, only ALPII was found to be suitable for the development of a sensitive procedure for $\mathrm{Mg}$ (II) determination.

\section{Choice of buffer solutions}

Various buffer solutions with different concentrations were tested in order to check whether they affected the degree of $\mathrm{Zn}$ (II) inhibiting and $\mathrm{Mg}$ (II) activating effects on the catalytic activity of the chosen alkaline phosphatases or not. The following buffer solutions with $\mathrm{pH} 9.8$ were studied: $5 \mathrm{mM}$ $\mathrm{Na}_{2} \mathrm{~B}_{4} \mathrm{O}_{7} / \mathrm{KOH}, 10 \mathrm{mM} \mathrm{NaHCO} / \mathrm{KOH}, 50 \mathrm{mM}$ Tris/ $\mathrm{HCl}$ and $100 \mathrm{mM}$ glycine/KOH. The concentrations of the buffer solutions corresponded to those, that provided the highest catalytic activity of the enzymes. 


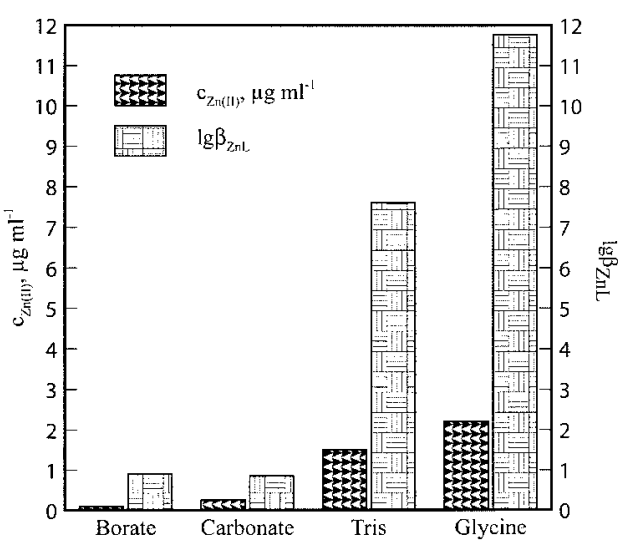

Fig. 2 Relationship between the concentration of zinc causing the inhibition of alkaline phosphatase from seal intestine in $50 \%$ and the logarithms of the stability constants of zinc complexes $\left(\lg \beta_{\mathrm{ZnL}}\right)$ with the components of $5 \mathrm{mM}$ borate, $10 \mathrm{mM}$ carbonate, $50 \mathrm{mM}$ Tris- $\mathrm{HCl}$ and $100 \mathrm{mM}$ glycine buffer solutions, $\mathrm{pH} 9.8$.

It was revealed that the degree of the $\mathrm{Zn}$ (II) inhibiting effect depended on the nature of the buffer solution in the indicator reaction. Among a number of buffer solutions (borate, carbonate, glycine and Tris- $\mathrm{HCl}$ ), borate buffer seemed to be the most promising one for maximum inhibition of phosphatase from seal intestine with $\mathrm{Zn}(\mathrm{II})$. Figure 2 shows that the higher was the logarithm of the stability constant of the zinc complex with the components of the buffer solutions (tetraborate-, carbonate-, Tris-, and glycine-ions), the higher was the concentration of zinc causing the same degree of inhibition, $50 \%$ in particular. The concentration of the buffer solution is also an important factor that affects the degree of inhibition of ALPII. Thus, it is evident that the application of borate buffer solution provides the highest sensitivity for $\mathrm{Zn}$ (II) determination.

To develop a procedure for magnesium determination, a Tris- $\mathrm{HCl}$ buffer solution was chosen the optimum. This buffer system is advantageous owing to the fact that its active component, Tris, contributes to the interaction between the enzyme and NPP in the presence of $\mathrm{Mg}(\mathrm{II}) .{ }^{28}$ Magnesium ions act as a bridge and facilitate the attachment of the substrate molecules to alkaline phosphatase. Moreover, the complex of Tris-ion with magnesium ion has a lower value of the stability constant. $^{27}$

Thus, we showed that while developing the enzymatic procedures for the determination of metal ions it is necessary to study the influence of the components of buffer solutions on the extent of metal ions action.

\section{Effect of the $\mathrm{pH}$}

The effect of the $\mathrm{pH}$ on the rate of the indicator reaction in the presence of zinc and magnesium is shown in Fig. 3. The experiments were carried out in $5 \mathrm{mM}$ borate and $50 \mathrm{mM}$ Tris- $\mathrm{HCl}$ buffer solutions in the presence of zinc and magnesium, respectively. The highest $\mathrm{Zn}$ (II) inhibiting and $\mathrm{Mg}$ (II) activating effects were observed in the range of $\mathrm{pH} 9.5$ 10.0 with the maximum at $\mathrm{pH} 9.8$. This optimum $\mathrm{pH}$ was chosen for further investigations.

\section{Effect of the incubation time}

We made an attempt to increase the inhibiting effect of $\mathrm{Zn}$ (II) and studied the dependence of the ALPIII inhibition degree on

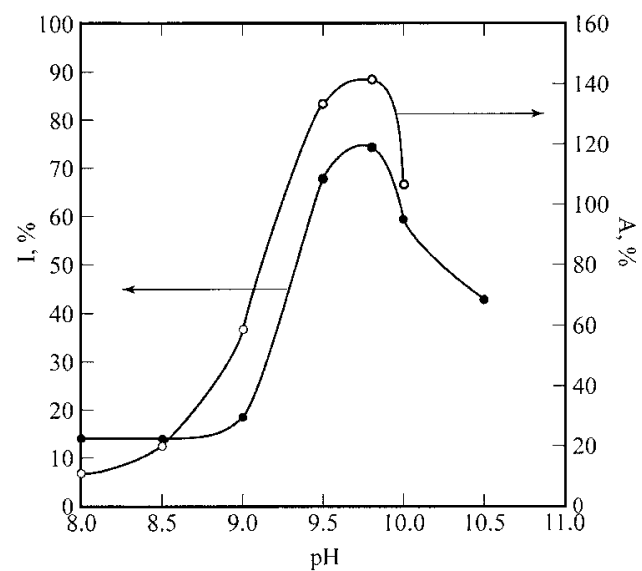

Fig. 3 pH-dependence of the degrees of inhibition $(I, \%)$ and activation $(A, \%)$ of alkaline phosphatases from seal and chicken intestine in the presence of $0.01 \mu \mathrm{g} \mathrm{ml}^{-1}$ zinc and $5 \mathrm{ng} \mathrm{ml}^{-1}$ magnesium, respectively.

the time of its preincubation with this metal ion in a $5 \mathrm{mM}$ borate buffer solution. The degree of ALPIII inhibition by $1 \mu \mathrm{g}$ $\mathrm{ml}^{-1} \mathrm{Zn}(\mathrm{II})$ (this concentration was taken as an example) did not change in the case of their preincubation for at least $30 \mathrm{~min}$. Besides, it was stated that zinc acted as a reversible incompetitive inhibitor of the enzyme activity in the reaction of NPP hydrolysis.

On the contrary, the preincubation of magnesium at its concentration of $2 \mathrm{ng} \mathrm{ml}^{-1}$ with ALPII during 5 min enhanced its activation degree by $\sim 50 \%$. Upon further incubation of a mixture containing $50 \mathrm{mM}$ Tris- $\mathrm{HCl}$ buffer, the enzyme and magnesium solutions did not change the activation degree. Moreover, $\mathrm{Mg}(\mathrm{II})$ activated ALPII after their $5 \mathrm{~min}$ preincubation at significantly lower $\left(0.6-20 \quad \mathrm{ng} \mathrm{ml}^{-1}\right)$ concentrations compared with those $\left(2-20 \mathrm{ng} \mathrm{ml}^{-1}\right)$ when the activator and enzyme were added to the indicator reaction without any preliminary incubation.

\section{Analytical data}

The calibration graphs for zinc and magnesium determination under the above-described optimum conditions were plotted. Table 1 presents the analytical characteristics of the developed enzymatic procedures. There exists a linear relationship between the rate of the indicator reaction and the concentration of magnesium in the range of $0.6-6.0 \mathrm{ng} \mathrm{ml}^{-1}$. In the case of zinc determination, the calibration graph is linear if it is plotted with the following coordinates: the rate of the reaction, logarithm of zinc concentration in the range of $0.01-1 \mu \mathrm{g} \mathrm{ml}^{-1}$.

The procedure based on the inhibiting effect of zinc(II) on the catalytic activity of ALPIII in a borate buffer solution is more sensitive than those for zinc determination by atomic-absorption spectrometry $\left(c_{\min }=0.5 \mu \mathrm{g} \mathrm{ml}^{-1}\right)^{29}$ and amperometry with the use of the reactivating effect of zinc on ALPI immobilized on a graphite electrode $\left(c_{\min }=65 \mathrm{ng} \mathrm{ml}{ }^{-1}\right){ }^{30}$ The developed procedure is less sensitive than those for zinc determination by stripping voltammetry $\left(5-200 \mathrm{ng} \mathrm{ml}^{-1}\right)$ and X-ray fluorescence with sorption preconcentration $\left(c_{\min }=4 \mathrm{ng} \mathrm{ml}^{-1}\right){ }^{31}$ and the enzymatic procedure based on the $\mathrm{Zn}$ (II) reactivating effect on the apoenzyme of alcohol dehydrogenase from baker's yeast $\left(0.05-0.5 \mathrm{ng} \mathrm{ml}^{-1}\right) .{ }^{32}$

The sensitivity of the developed technique for magnesium determination based on its activating effect on the catalytic activity of ALPIII is higher than that of the procedures for its 
Table 1 Analytical characteristics of the procedures for the determination of $\mathrm{Zn}$ (II) and $\mathrm{Mg}$ (II) using alkaline phosphatases from slim intestine of a Greenland seal (I) and chicken intestine (II), $\mathrm{pH} 9.8$

\begin{tabular}{ccccc}
\hline \multicolumn{1}{c}{ Buffer } & Enzyme & Applicable concentrations range $/ c_{\min ^{\mathrm{a}}}$ & Calibration equation & RSD, \% at $c_{\mathrm{L}}{ }^{\mathrm{b}}$ \\
\hline $5 \mathrm{mM}$ Borate & $\mathrm{I}$ & $\mathrm{Zn}$ (II)-inhibitor $0.01-0.1 \mu \mathrm{g} \mathrm{m}^{-1}\left(3 \mathrm{ng} \mathrm{ml}^{-1}\right)$ & $y=-1.34-4.58 x^{\mathrm{c}}$ & 14 \\
$50 \mathrm{mM}$ Tris-HCl & $\mathrm{II}$ & $\mathrm{Mg}(\mathrm{II})$-activator $0.6-6 \mathrm{ng} \mathrm{m}^{-1}\left(0.2 \mathrm{ng} \mathrm{ml}^{-1}\right)$ & $y=3.30+0.53 x$ & 4 \\
\hline
\end{tabular}

a. The concentration of an analyte that produced an analytical signal equal to three-times the standard deviation $(3 \sigma)$ of the background, rate. b. At the lower limits of determination, $n=5$. c. $y, v_{\mathrm{o}}\left(\mu \mathrm{M} \mathrm{min}^{-1}\right) ; x, \log c_{\mathrm{Zn}(\mathrm{II})}\left(\mu \mathrm{g} \mathrm{ml}^{-1}\right)$ or $c_{\mathrm{Mg}_{\mathrm{g}}(\mathrm{II})}\left(\mathrm{ng} \mathrm{ml}^{-1}\right)$.

Table 2 Effects of foreign ions on the determination of 0.01 $\mu \mathrm{g} \mathrm{ml} l^{-1}$ zinc(II) and $0.06 \mathrm{ng} \mathrm{ml}^{-1}$ magnesium(II) using the proposed enzymatic procedures

\begin{tabular}{cccl}
\hline $\begin{array}{c}\text { Analyte } \\
(\mathrm{Me})\end{array}$ & $\begin{array}{c}\text { Alkaline } \\
\text { phosphatase }\end{array}$ & $\begin{array}{c}\text { Tolerance limit } \\
\text { foreign ion/Me }\end{array}$ & Foreign ion \\
\hline $\mathrm{Zn}(\mathrm{II})$ & Seal & $2.5 \times 10^{5}$ & $\mathrm{~K}(\mathrm{I})$ \\
& intestine & $7.0 \times 10^{5}$ & $\mathrm{Cs}(\mathrm{I})$ \\
& & $2.0 \times 10^{4}$ & $\mathrm{Mg}(\mathrm{II})$ \\
& & $4.0 \times 10^{4}$ & $\mathrm{Ca}(\mathrm{II})$ \\
& & $>10^{2}$ & $\mathrm{Mn}(\mathrm{II}), \mathrm{Cu}(\mathrm{II}), \mathrm{Ni}(\mathrm{II}), \mathrm{Cd}(\mathrm{II})$, \\
$\mathrm{Mg}(\mathrm{II})$ & Chicken & $>10^{5 \mathrm{a}}$ & $\mathrm{Co}(\mathrm{II}), \mathrm{Fe}(\mathrm{III})$ \\
& intestine & & $\mathrm{Ni}(\mathrm{II}), \mathrm{Co}(\mathrm{II}), \mathrm{Al}(\mathrm{III}), \mathrm{Cu}$ (II), \\
& & $10^{5}$ & $\mathrm{Ca}(\mathrm{III}), \mathrm{Ba}$ (II) \\
& & $10^{3}$ & $\mathrm{Zn}(\mathrm{II})$ \\
& & $10^{2}$ & $\mathrm{Cd}(\mathrm{II})$ \\
& & & $\mathrm{Pb}(\mathrm{II})$ \\
\hline
\end{tabular}

a. Maximum ratio tested.

determination by atomic-absorption and atomic emission spectrometry $\left(c_{\min }=10 \mathrm{ng} \mathrm{ml^{-1 }}\right), 33$ and the fluorometric procedure based on the formation of a magnesium complex with 8-hydroquinoline-5-sulfo acid $\left(c_{\min }=12 \mathrm{ng} \mathrm{ml}^{-1}\right) ; 3$ it is comparable to the sensitivity of the procedures using inductively coupled plasma mass spectrometry $\left(c_{\min }=0.1 \mathrm{ng}\right.$ $\left.\mathrm{ml}^{-1}\right)^{23}$ and only one enzymatic procedure based on the magnesium-activated bioluminescence conversion of luciferin into hydroxyluciferin in the presence of ATP catalyzed by firefly luciferase immobilized on $\mathrm{Br}-\mathrm{CN}$-sepharose $\left(c_{\min }=0.1\right.$ ng ml-1). ${ }^{35}$

\section{Effect of foreign species}

To ascertain the selectivity of the developed procedures, the influence of some foreign metal ions on the reaction rate under the optimum conditions and at constant zinc and magnesium concentrations of $1 \mu \mathrm{g} \mathrm{ml}^{-1}$ and $0.6 \mathrm{ng} \mathrm{ml}^{-1}$, respectively, was studied following the basic procedure. The interference of those metal ions, which commonly accompanies $\mathrm{Zn}$ (II) and $\mathrm{Mg}$ (II) in pharmaceuticals and biological samples and are able to substitute them in binding enzyme sites was tested.

The tolerance was defined as the concentrations of foreign species that produced an error exceeding $5 \%$ in the value of the reaction rate. The results are summarized in Table 2. The interfering effect of foreign ions may be caused by their competition with zinc for binding sites in the molecule of ALPIII and by their partial substitution of magnesium ions in the allosteric site of ALPII. As one can see from Table 2, the tolerant levels of foreign ions concentrations in the case of the both developed techniques are rather high.

Thus, the proposed procedures for zinc and magnesium determination are not only sensitive, but also selective.

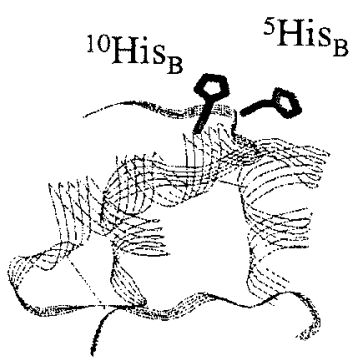

INS monomer

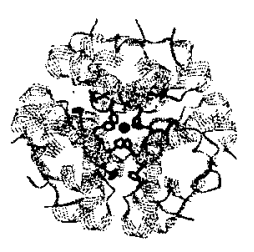

top view

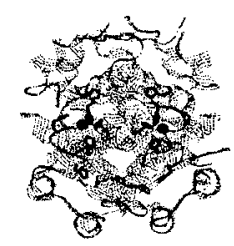

side view

\section{INS hexamer complexed with $\mathrm{Zn}^{2+}$}

Fig. 4 Structure of the insulin monomer and hexamer, where ${ }^{5} \mathrm{His}_{\mathrm{B}}$ is in grey and ${ }^{10} \mathrm{His}_{\mathrm{B}}$ is in black. ${ }^{21}$

\section{Application}

The proposed procedures were applied to the determination of analytes in real samples.

Determination of zinc in IZS injection using alkaline phosphatase from seal slim intestine

According to Hovorka et al., ${ }^{21}$ the B chain of the insulin monomer contains two histidine (His) residues, ${ }^{5} \mathrm{His}_{\mathrm{B}}$ and ${ }^{10} \mathrm{His}_{\mathrm{B}}$. Three insulin dimers aggregate in the presence of zinc ions into a torus-shaped hexamer with two zinc-binding sites. Each binding site is comprised of three ${ }^{10} \mathrm{His}_{\mathrm{B}}$ imidazole ligands with the corresponding ${ }^{5} \mathrm{His}_{\mathrm{B}}$ residues in a close proximity (Fig. 4). In other words, zinc forms a complex with insulin. Besides, it is known $^{36}$ that insulin inhibits the catalytic activity of alkaline phosphatase in vivo due to the direct interaction involving either disulfide cross linkages or the metal chelating activity of insulin. Thus, it was necessary to decompose an IZS sample before introducing it into the indicator system. For this purpose we used the technique presented in Experimental part. Note, that the same procedure for IZS decomposition is commonly applied for preparing insulin samples for analysis by atomic-absorption spectrometry. This procedure is recommended by the Pharmaceutical Committee of Russian Ministry of Health for determining zinc in IZS.

The dependence of the indicator reaction rate on the concentration of hydrochloric acid used to decompose IZS 


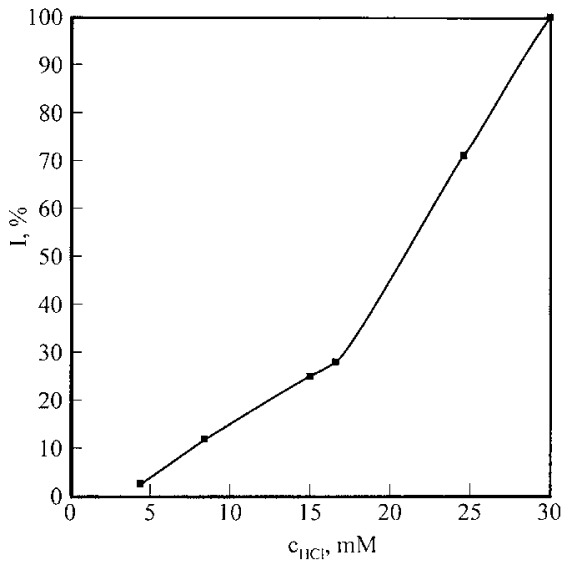

Fig. 5 Dependence of the degree of inhibition of alkaline phosphatase from seal intestine on $\mathrm{HCl}$ concentration in $5 \mathrm{mM}$ borate buffer solution, $\mathrm{pH} 9.8$.

injection was studied. It was found necessary to keep the concentration of hydrochloric acid (introduced with the insulin sample) as low as possible in order to avoid a shift of the $\mathrm{pH}$ optimum value and considerable inhibition $(I>25 \%)$ of the catalytic activity of ALPIII by chloride ions. Such a shift did not take place when the concentration of $\mathrm{HCl}$ in the reaction mixture was less than $15 \mathrm{mM}(5 \mathrm{mM}$ borate buffer solution, $\mathrm{pH}$ 9.8). This conclusion was made based on the data presented in Fig. 5.

The volume of the insulin sample was also optimized. The rate of the indicator reaction decreased by 3 -fold after introducing $0.1 \mathrm{ml}$ of an insulin solution decomposed as described above. When standard additions of a zinc and insulin sample were introduced into the reaction mixture, considerable inhibition hampered fixing the reaction rate. However, the degree of inhibition did not practically depend on the concentration of added zinc. To reduce the interfering effect of the insulin matrix, the decomposed sample was 10-times diluted by deionized water, and was then introduced into the reaction mixture.

To eliminate any interfering effect of the organic components of the analyzed solution of insulin (and methylparabene, first of all) on the results of zinc determination, analysis was performed by the addition method according to Experimental part.

It was found that the zinc content in the pharmaceutical preparation equaled $24.3 \pm 0.7 \mu \mathrm{g} \mathrm{ml}^{-1}$ (mean $\pm 95 \%$ confidence limit for 5 replicate analyses) and correlated well enough with the data indicated by the producer $\left(\leq 30 \mu \mathrm{g} \mathrm{ml}^{-1}\right)$ and the results obtained by the method of atomic-absorption spectrometry ( 24 $\left.\mu \mathrm{g} \mathrm{ml}^{-1}\right)$.

Determination of magnesium in urine using alkaline phosphatase from chicken intestine

Urine samples of 6 female patients aged between 5 and 50 were analyzed using the developed technique for magnesium determination. To determine magnesium in urine samples, the method of standard additions was used. The results of magnesium determination in urine samples are summarized in Table 3.

To underline the practical importance of the developed technique for magnesium determination, we also studied the pharmaceutical effect of the Mg-containing preparation "Magnerot" (Worwag Pharma, Germany) on patients' health. Magnesium orotate is an active compound of this preparation. The usefulness of "Magnerot" for the treatment of $\mathrm{Mg}$ -
Table 3 Results of magnesium determination in urine using its activating action on the catalytic activity of alkaline phosphatase from chicken intestine; normal content (100 - $300 \mathrm{mg}$ /day)

\begin{tabular}{|c|c|c|c|c|}
\hline \multirow{2}{*}{$\begin{array}{c}\text { Patient age/ } \\
\text { year }\end{array}$} & \multicolumn{3}{|c|}{ Magnesium(II) found } & \multirow{2}{*}{$\begin{array}{l}\text { Possible reasons } \\
\text { of } \mathrm{Mg} \text {-deficiency }\end{array}$} \\
\hline & $\begin{array}{c}\text { In aliquot }{ }^{\mathrm{a}} / \\
\mu \mathrm{g} \mathrm{ml}^{-1}\end{array}$ & $\pm^{\mathrm{b}}$ & $\begin{array}{l}\text { In urine } / \\
\text { mg on day }\end{array}$ & \\
\hline 5 & 18.0 & 0.6 & 14.4 & $\begin{array}{l}\text { Increasing } \\
\text { excitability, } \\
\text { weak immunity }\end{array}$ \\
\hline 15 & 17.4 & 0.1 & 20.9 & Low calorie diet \\
\hline 20 & 15.0 & 1.8 & 21.0 & Low calorie diet \\
\hline 25 & 15.0 & 1.8 & 27.0 & $\begin{array}{l}\text { Physical efforts, } \\
\text { chronicle tiredness, } \\
\text { hypertension, } \\
\text { sleeplessness }\end{array}$ \\
\hline 30 & 8.4 & 0.2 & 12.6 & $\begin{array}{l}\text { Gall-stones in the } \\
\text { liver, thyroid } \\
\text { gland disease }\end{array}$ \\
\hline 50 & 6.0 & 0.1 & 10.8 & $\begin{array}{l}\text { Using diuretics, } \\
\text { hypertension }\end{array}$ \\
\hline
\end{tabular}

a. Aliquot of the sample, $6.00 \mathrm{ml}$, after treatment.

b. Mean $\pm 95 \%$ confidence limit for 5 replicate analyses.

c. Urine was collected during $24 \mathrm{~h}$.

deficiency caused by different reasons was recognized long ago.

The fourth patient (Table 3) was selected for carrying out the experiment. He took the "Magnerot" preparation within one week according to a doctor's recommendation. His urine was collected and analyzed every day as described above.

The accuracy of the results of magnesium determination in a urine sample of the indicated patient obtained by the proposed enzymatic method was checked using two alternative methods: atomic-absorption spectrometry and spectrophotometry with xylidil blue. ${ }^{37}$ The data presented in Table 4 show a rather good correlation with the results obtained by different methods.

Thus, the developed procedures for zinc and magnesium determination might be considered to be alternative techniques to the atomic-absorption method having at the same time the additional advantage of using inexpensive instruments.

\section{Conclusions}

The obtained results demonstrate the prospects of adapting two different approaches to improve the sensitivity and the selectivity of the enzymatic procedures for the determination of metal ions, zinc and magnesium: using preparations of the same enzyme isolated from diverse sources, alkaline phosphatases isolated from seal and chicken intestine, and varying the nature of a buffer solution in the reaction system.

High sensitivity and selectivity in combination with simple spectrophotometric control of the rate of the indicator reaction make these procedures appropriate and promising for applications into pharmaceutical and clinical analyses. The examples of determining zinc in insulin suspension and magnesium in urine samples demonstrate the possibilities of these procedures.

\section{Acknowledgements}

This work was supported by the Russian Foundation for Basic Research (Grant No. 04-03-33116). 
Table 4 Results of magnesium determination in urine obtained by enzymatic, atomic-absorption and spectrophotometric methods on the time of taking "Magnerot"

\begin{tabular}{cccc}
\hline \multirow{2}{*}{ Day } & \multicolumn{3}{c}{ Magnesium(II) found/mg on day } \\
\cline { 2 - 4 } & $\mathrm{P}^{\mathrm{a}}$ & $\mathrm{R}_{1}{ }^{\mathrm{b}}$ & $\mathrm{R}_{2}{ }^{\mathrm{c}}$ \\
\hline 0 & 27.0 & 29.0 & 23.5 \\
1 & 37.4 & 38.0 & 33.8 \\
2 & 65.5 & 65.9 & 60.7 \\
3 & 69.1 & 70.0 & 70.5 \\
4 & 105.5 & 106.8 & 105.0 \\
5 & 134.5 & 134.0 & 130.9 \\
6 & 144.8 & 145.5 & 141.3 \\
7 & 163.6 & 164.3 & 160.0 \\
\hline
\end{tabular}

a. P, Proposed method.

b. $R_{1}$, Atomic-absorption method.

c. $\mathrm{R}_{2}$, Spectrophotometric method. ${ }^{37}$

\section{References}

1. T. G. Spiro, in "Inorganic Biochemistry", ed. G. L. Eichorn, 1973, Vol. 1, Elsevier, Amsterdam, 549.

2. H. N. Frenley, in "The enzymes", ed. P. D. Boyer, 3rd ed., 1971, Vol. 4, Academic Press, New York, 417.

3. D. W. Moss, Clin. Chem., 1982, 28, 2007.

4. S. Iino, Nippon Rinsho (in Japanese), 1995, 53, 1157.

5. J. A. Lorente, J. Morote, C. Raventos, G. Encabo, and H. Valnzuela, J. Urol., 1996, 155, 1348.

6. J. M. Van Emon, J. AOAC Int., 2001, 84, 125.

7. D. Trau, T. Theueri, M. Wilner, M. Meusel, and F. Spener, Biosens. Bioelectron., 1997, 12, 499.

8. S. V. Muginova, A. M. Zharvoronkova, and T. N. Shekhovtsova, J. Anal. Chem., 2005, 60, 218.

9. T. N. Shekhovtsova and S. V. Muginova, Anal. Bioanal. Chem., 2005, 381, 1328.

10. T. N. Shekhovtsova, S. V. Muginova, I. A. Veselova, and M. A. Karkeshkin, in Proceedings of International Conference on Instrumental Methods of Analysis, Modern Trends and Applications, 2005, University of Crete, Heraklion, Crete, 245.

11. R. L. Dean, Biochem. Mol. Biol. Educ., 2002, 30, 401.

12. R. Cloetens, Arch. Int. Pharmacodyn., 1942, 68, 419.

13. R. Cloetens, Arch. Int. Pharmacodyn., 1944, 69, 389.

14. R. A. Anderson, W. F. Bosron, F. S. Kennedy, and B. L. Vallee, Biochemistry, 1975, 72, 2989.

15. N. A. Bagirova, S. V. Muginova, T. N. Shekhovtsova, I. G.
Gazaryan, and R. B. van Huystee, Anal. Lett., 2006, 39, 521.

16. P. V. Bychkov, T. N. Shekhovtsova, and E. R. Milaeva, Bioinorg. Chem. Appl., 2005, 3, 191.

17. T. N. Shekhovtsova, N. A. Bagirova, and R. B. van Huystee, Talanta, 2001, 55, 1151.

18. T. N. Shekhovtsova, S. V. Muginova, J. A. Luchinina, and A. Z. Galimova, Anal. Chim. Acta, 2006, 573 - 574, 125.

19. P. V. Bychkov and T. N. Shekhovtsova, Mendeleev Commun., 2003, 2, 75.

20. M. A. Koupparis and P. I. Anaqnostopoulou, Analyst, 1986, $111,1311$.

21. S. W. Hovorka, H. Biesiada, T. D. Williams, A. Hühmer, and C. Schöneich, Pharm. Res., 2002, 19, 530.

22. I. D. Molger, A. C. Truttmann, R. O. von Vigier, A. Bettinelli, G. P. Ramelli, and M. G. Bianchetti, Pediatr. Nephrol., 1999, 13, 50.

23. C. Wallace, Emergency Medicine, 2003, 15, 92.

24. M. M. Farajollahi, D. B. Cook, and C. H. Self, Iran. Biomed. J., 2002, 6, 105.

25. R. Cloetens, Biochem. Z., 1941, 307, 352.

26. A. M. Zharvoronkova, S. V. Muginova, and T. N. Shekhovtsova, Moscow University Bulletin, 2003, 44, 123.

27. R. M. C. Dawson, D. C. Elliott, W. H. Elliott, and K. M. Jons, "Data for Biochemical Research", 1986, Clarendon Press, Oxford, 592.

28. A. Mildvan, in "The enzymes", ed. P. D. Boyer, 3rd ed., 1971, Vol. 2, Academic Press, New York, 448.

29. G. I. Tsizin, E. M. Sedykh, L. N. Bannykh, N. M. Sorokina, and Yu. A. Zolotov, J. Anal. Chem., 1995, 50, 72.

30. J. J. Jasaitis, V. J. Rasumas, and J. J. Kulys, Anal. Chim. Acta, 1983, 152, 271.

31. V. P. Zhivopistsev and E. A. Selesneva, "Analyticheskaya Khimiya Tsinka (Analytical Chemistry of Zinc, in Russian)", 1975, Nauka, Moscow.

32. T. N. Shekhovtsova, S. V. Muginova, and I. A. Veselova, Ross. Khim. Zh., 2004, XLVIII, 95.

33. D. L. Tsalev, "Atomic-Absorption Spectrometry in Occupational and Environmental Health Practice", Vol. III, "Progress in Analytical Methodology", 1995, CRC Press, Boca Raton, Florida, 349.

34. G. Armas, A. Cladera, E. Beccerra, J. M. Estela, and V. Cerda, Talanta, 2000, 52, 77.

35. T. N. Shekhovtsova, S. V. Chernetskaya, N. V. Belkova, and I. F. Dolmanova, J. Anal. Chem., 1994, 49, 709.

36. C. Gazzarrini, N. Stagni, P. Pollesello, P. D. Andrea, and B. De Bernard, Acta Diabetol. Lat., 1989, 26, 321.

37. C. K. Mann and J. H. Yoe, Anal. Chem., 1956, 28, 202. 